\title{
Covid-19 Bağlamında Zorunlu Aşı Tartışmalarının Hukuki Boyutu
}

\section{The Legal Dimension of Mandatory Vaccine Discussions in the Context of Covid-19}

\section{Sevtap Metin ${ }^{1}$ (D)}

\footnotetext{
İstanbul Üniversitesi, Hukuk Fakültesi, Hukuk Felsefesi ve Sosyolojisi Anabilim Dalı, İstanbul, Türkiye
}

ORCID: S.M. 0000-0002-5961-5216

Sorumlu Yazar/Corresponding Author: Sevtap Metin,

İstanbul Üniversitesi, Hukuk Fakültesi, Hukuk Felsefesi ve Sosyolojisi Anabilim Dal, İstanbul, Türkiye

E-posta: sevtap_metin@hotmail.com

Başvuru/Submitted: 26.06 .2021

Revizyon Talebi/Revision Requested: 12.09.2021 Son Revizyon/Last Revision Received: 14.09.2021 Kabul/Accepted: 23.09.2021

Online Yayın/Published Online: 26.10.2021

Atıf/Citation: Metin S. The legal dimension of mandatory vaccine discussions in the context of Covid 19. Sağlık Bilimlerinde İleri Araştırmalar Dergisi 2021; 4(Suppl.1): S37-S50. https://doi.org/10.26650/JARHS2021-958025
ÖZ

Amaç: Çalışma, COVID-19 pandemisinde geliştirilen aşıların uygulanmasının, hukuki açıdan zorunlu tutulup tutulamayacağı meselesinin gerek uluslararası hukuk gerekse iç hukuk düzeni açısından analiz edilmesini amaçlamaktadır.

Gereç ve Yöntem: Çalışma kapsamında gerek Avrupa İnsan Hakları Mahkemesi’nin (AİHM) gerek Türk Anayasa Mahkemesi’nin (AYM) genel olarak aşların zorunlu tutulup tutulamayacağı ve bunun hukuki koşullarını gösteren mahkeme içtihatları taranmıştır. Bu verilerden elde edilen sonuçlar ile hukuki normatif analiz yapılmış ve daha sonra benzetme/ analoji yönteminden yararlanılarak COVID-19 aşılarına uygulanmıştır.

Bulgular: COVID-19 aşılarının zorunlu tutulması halinde bu durum halihazırdaki hukuk düzenimizde yasallık koşulunu bütün unsurlarıyla karşılamadığından temel hak ve özgürlüklere müdahale teşkil edecektir.

Sonuç: Yapıldığı dönem itibariyle oldukça başarılı olsa da 1930 tarihli Umumi Hıfzısıhha Kanunu ihtiyacı karșılamaktan uzaktır. COVID-19 pandemi salgını ile mücadelede geliștirilen aşıların olunması zorunlu tutulduğu takdirde, buna uymayanların ne tür yaptırımlarla karşılaşabileceğine dair Umumi Hıfzısıhha Kanunu’nda açıklık bulunmamaktadır. Bugün için idarenin genel sağlık alanındaki yetkilerinin günümüz koşullarına uygun şekilde kanunla yeniden düzenlenmesi gerekmektedir.

Anahtar Kelimeler: Zorunlu aşılama, Covid-19 aşıları, Umumi Hıfıısıhha Kanunu, orantılılık ilkesi

\section{ABSTRACT}

Objective: The study aims to analyze the issue of whether the application of vaccines developed in the COVID-19 pandemic can be legally enforced in terms of both international law and domestic law.

Materials and Methods: Within the scope of the study, the jurisprudence of both the European Court of Human Rights and the Turkish Constitutional Court, which shows whether vaccinations can be made compulsory in general and the legal conditions of this, has been scanned. Legal normative analysis was made with the obtained data and then it was applied to COVID-19 vaccines by using the analogy method.

Results: If COVID-19 vaccines are made compulsory, this situation will constitute an interference with fundamental rights and freedoms, as it does not meet the legality requirement in all aspects in our current Turkish legal system.

Conclusion: Although it was quite successful in the period it was made, the 1930 Public Health Law is far from meeting the needs. There is no clarity in the Public Health Law on what kind of sanctions may be faced by those who do not comply, if the vaccines developed in the fight against the COVID-19 pandemic epidemic are made mandatory. Today, the authorities of the administration in the field of general health need to be rearranged by law in accordance with today's conditions.

Keywords: Mandatory Vaccination, COVID-19 vaccines, proportionality principle, Public Health Law 


\section{GİRIŞ}

Çinliler tarafından M.Ö. 1000'li yıllardan itibaren uygulanan aşı ve aşılama, modern tıbbın önemli başarılarından biri kabul edilmektedir (1). Aşılama yöntemleriyle geçmişte milyonlarca insanın ölümüne veya sakat kalmasına neden olan çiçek hastalığı yeryüzünden silinmiş, çocuk felci (polio) ortadan kaldırılma düzeyine inmiş ve kızamık, kabakulak, kızamıkçık, boğmaca, difteri, bulaşıcı sarılık (hepatit) gibi hastalıkların yayılmaları birçok ülkede büyük oranda engellenmiştir. Hayvanlardan geçen hastalıkları önlemek amacıyla da aşılar dünyada yaygın olarak kullanılmaktadır (2).

İnsanın vücut bütünlüğüne doğrudan ya da dolaylı olarak müdahaleyi gerektirmekle tıbbi müdahaleler, kişinin özgür ve aydınlatılmış onamı alındıktan sonra yapılabilir. Yeterli bilgilendirmenin yapılmasindan sonra, hastanın tedaviye onam verme hakkı olduğu gibi reddetme hakkı da vardır (3). Aşı da insan vücuduna yapılan tıbbi bir müdahale (1) olduğuna göre o halde kişiler rızaları olmasa dahi zorunlu aşı uygulamasına tabi tutulabilirler mi? İşte bu sorunun cevabını aynı zamanda COVID-19 aşıları bağlamında kendi hukuk düzenimiz açısından bulmaya çalışacağız. Yöntem olarak ise parçadan bütüne gidilerek; önce mahkeme kararlarında konunun ve ilgili hukuk kurallarının nasıl anlaşılıp, yorumland1ğına bakılacak ve bunlardan hareketle genel bir sonuca ulaşmaya çalışılacaktır. Makale başlığı COVID-19 aşılarının uygulanmasıdır lakin bu konu ile ilgili henüz yargı organlarına aksetmiş hukuki bir uyuşmazlık bilinmemekle ${ }^{1}$; diğer zorunlu aşı uygulamaları hakkında yapılan hukuki tartışma ve gerekçelendirmeler bu hususta bize yol gösterecektir.

Ancak başlangıç noktasında yapılması gerekenlerden biri ise aşının zorunlu olmasından ne anlaşılacağının belirlenmesidir. Aşı kavramı; "zorunlu” ve "yapılması tavsiye edilen" olarak ikili bir sinıflandırmaya tabi tutulur. Bunlardan yapılması devlet tarafından üstlenilen ve kişilerin bu aşıları reddetmesi durumunda ülkeden ülkeye değişmekle birlikte çeşitli yaptırımların öngörüldüğü aşılar, "zorunlu aşı" olarak nitelenmektedir $(4,5)$. Zorunlu aşıdaki zorun- luluktan kasıt, kamu gücü kullanılarak uygulanması mecburi kılınmış ve reddedilmesi çeşitli yaptırımlara bağlanmış bir hukuki düzenlemedir. Zorunlu aşı politikasını takip eden ülkelerde bir veya daha fazla aşının zorunlu tutulması ve buna paralel olarak aşılarını olmamış çocukların okula kaydolamaması ya da çocuklarına aşı yaptırmayan ailelere idari para cezası verilmesi gibi yaptırımlar söz konusu olabilmektedir. Nitekim modern dönemde zorunlu aşı uygulamalarının ilk örneklerinden olan ve Amerika Birleşik Devletleri'nde 1900'lerin başında çiçek hastalığı salgını sırasında Massachusetts eyaletinin yetişkinler için hükümet düzeyinde zorunlu çiçek aşısı yapılmasını onayladığı örnekte de benzer yaptırımlara rastlarız. 1902'de Massachusetts Sağlık Kurulu, eyalet yasama organı tarafından kendisine verilen yetkiyi kullanarak, 21 yaşın üzerindeki tüm sağlıklı sakinler için aşılama yetkisi almış, reddedenlere günde beş dolar para cezası öngörmüştü. Henning Jacobson adındaki bir papaz, bu para cezasını ödemeyi reddettiği için kovuşturulmuş ve nihayetinde Jacobson/ Massachusetts davası vesilesi ile ABD Yüksek Mahkemesi, devletin belirli koşullar altında aşılamaya zorlama hakkını destekleyen kararını açıklamıştır $(6,7)$.

Buna karşın devlet tarafından yapılması zorunlu tutulmamış ve bir yaptırıma bağlanmamış, bununla birlikte kişilerin yaptırmasında fayda bulunan aşılar, yapılması "tavsiye edilen" aşılardır. Tıbbi bir müdahale olmakla rızayı/onamı gerektiren ihtiyari aşılardan farkla, rıza aranmayan ve kişinin kendi ile ilgili tıbbi kararları almasında otonomi ilkesi ile çelişen zorunlu aşı uygulamaları, hukuki temele oturtulabilir mi? Şayet hukuka uygun olacaksa hangi koşullar bunu sağlar? Buradan hareketle COVID-19 aşıları için de aynı gerekçeler benzetme yoluyla geçerli olabilir mi? O halde genel olarak zorunlu aşı müdahalelerinin gerek iç, gerek uluslararası mahkemelerde nasıl ele alınıp, ilgili hukuk normlarının nasıl yorumlandığından hareket ile COVID-19 aşıları için de analoji yani benzetme yönteminden yararlanabiliriz. Bu bağlamda ilk önce uluslararası hukuk ve Türkiye’nin de halihazırda hukuken bağlı olduğu Avrupa

1 Bu konunun da hukuki bir uyuşmazlık konusu olarak yakın gelecekte yargı organları önüne aksedebileceğini öngörebiliriz. 
İnsan Hakları Sözleşmesi ve Sözleşmeye aykırılıkları inceleyen Avrupa İnsan Hakları Mahkemesi Kararları ile başlayalım.

\section{Zorunlu Așı Konusunda Mahkeme Kararla-} r1

1. Avrupa İnsan Hakları Mahkemesi Kararları

Zorunlu aşı konusu ile ilgili Avrupa İnsan Hakları Mahkemesi önüne gelen ve 1998 yılında görülen Carlo Boffa/V. San Marino Davası'nda başvurucu, sağlık bakanlığı tarafından yaptırılması talep edilen aşıları çocuklarına yaptırmamıştır. Başvurucu; aşıyla bağlantılı ölüm oranlarının yüksek olması karşısında; aşının zorunlu tutulmasının, Avrupa İnsan Hakları Sözleşmesỉnin 2. maddesinde düzenlenen yaşam hakkının ve ayrıca çocuklarının aşı olup olmayacağına dair kararın kendisine bırakılmamasının da sözleşmenin 8. maddesinin ihlali olduğunu öne sürmüştür (8).

AİHM'in 2012 yllında verdiği Solomakhin/Ukrayna kararında ise ilk davadan farklı olarak bu defa aşılanan başvurucu, otuz dört yaşında bir yetişkindir. Başvurucu, rızası hilafına uygulanan difteri aşısının yan etkisi sonucu kronik hastalığa yakalandığ 1 ve bu nedenle zorunlu aşının hukuka aykırı şekilde özel yaşama saygı hakkına müdahale ettiğini ileri sürmüştür (9).

Avrupa İnsan Hakları Mahkemesi'nden gelen ve Nisan 2021 tarihli en yeni kararda, zorunlu aşılarını yaptırmamaları nedeniyle çocukları kreşe kabul edilmeyen bir grup Çekyalı ailenin açtığı dava görüşülmüştür (10).

Özel yaşamın gizliliği ya da mahremiyet hakkı, kişinin özel yaşamının başkalarından gizli tutulması anlamının ötesinde daha geniş bir kavram olup; Avrupa İnsan Hakları Sözleşmesi’nin 8. maddesinin koruduğu değerlerden birisi de kişinin fiziksel ve zihinsel bütünlüğüdür. Tibbi bir müdahale olan zorunlu aşı, Mahkeme kararlarında fiziksel bütünlük hakkı kapsamında incelenmiş ve yukarıda zikredilen davalarda verdiği kararlarda, zorunlu aşıların 8. maddeye yönelik bir müdahale teşkil ettiği belirlemesinde bulunmuştur $(4,11)$.

Ancak hakka yönelik bir müdahale söz konusu olsa bile bu müdahalenin yine de hukuka uygun ol- ması mümkündür. Hakka yönelik müdahaleyi hukuka uygun hale getiren üç unsur, 8.maddenin 2. fikrasında belirlenmiştir. Bu şartlardan ilki, özel yaşama saygı hakkına yapılacak bir müdahalenin öncelikle kanuni bir dayanağının mevcut bulunması yani hakkın ancak yasa ile sınırlanabileceğidir. Hakkı sınırlayan yasal bir dayanağın varlığı dışında ikinci şart, müdahalenin meşru amaçlara ulaşmak için yapılmış olması ve üçüncü ise müdahalenin demokratik bir toplumda gerekli olmasıdır. Böylece meşru bir amaçla gerçekleştirilen müdahalenin demokratik bir toplumda ölçülü bir müdahale olması beklenir (11). Yargısal ve bilimsel içtihatlar ile geliştirilen ölçülülük ilkesi; elverişlilik, gereklilik ve orantılılık unsurlarından oluşmaktadır.

Elveriş̧lilik; yasal dayanağa sahip bir sınırlamanın, güdülen meşru amacı gerçekleştirmek için yeterli ve elverişli olmasıdır.

Gereklilik; ulaşılmak istenen amaç için sınırlamanın zorunlu görülmesidir.

Orantılılık ise varılmak istenen hedef ile sinırlama arasında ölçülü ve makul bir dengenin bulunmasidir.

Avrupa İnsan Hakları Mahkemesi, zorunlu aşı uygulamalarıyla ilgili verdiği içtihatlarında özet olarak; zorunlu aşılamanın, yasayla ve bulaşıcı bir hastalığın yayılmasını önlemek suretiyle halk sağlığını korumak gibi meşru bir amaçla yapıldığını belirtmiştir. Kişinin kendi menfaatlerini gerçekleştirmesine engel olmayan ve yaşamını tehlikeye atmayan bir zorunlu aşı politikası, devletin ilgili konuda takdir marjını aşmamakta ve demokratik bir toplumda gereklilik şartını ihlal etmemektedir. Görüldügüü üzere; kanunilik şartını sağladığı tespit edilen zorunlu aşılama müdahaleleri açısından, bireyin vücut bütünlüğünün korunmasına ilişkin menfaati karşısında kamu sağlığının korunması menfaatine üstünlük tanındığ1 ve söz konusu müdahalelerin özel hayata saygı hakkını ihlal etmediğine hükmedilmektedir. Mahkeme’nin üzerinde durduğu zorunlu aşının "ilgili kişinin hayatı bakımından tehlike yaratmaması”, "zorunlu aşılamanın birey üzerindeki yükünün, aşısiz toplum üzerindeki yükten daha hafif olması" hususları ayrıca önem taşımaktadır $(10,11)$. 
2. Zorunlu Așı Uygulamaları Konusunda Türk Anayasa Mahkemesi Kararları

Zorunlu aşılarla ilgili verdiği bir dizi karardan 2015 tarihli olan ve bireysel şikâyet yoluyla önüne gelen Halime Sare Aysal Başvurusunda Türk Anayasa Mahkemesi, ailenin rızası alınmaksızın çocukluk dönemi aşılarının yapılıp yapılamayacağına ilişkin değerlendirmelerini yapmıştır (12). Akabinde çocukları Muhammed Ali Bayram’a aşı yaptırmayı reddetmeleri üzerine, tedbir kararı alınarak çocuğun aşılanmasına ilişkin verilen kararda da, Halime Sare Aysal Başvurusunda yapılan değerlendirmeler benimsenmiştir (13). Halime Sare Aysal davasına konu olayda da Aile ve Sosyal Politikalar Bakanlığı'nın müracaatı üzerine Asliye Hukuk Mahkemesi, "Genişletilmiş Bağışılklama Programında” yer alan aşıların önemi hakkında ailenin bilgilendirilmesine rağmen izin vermemesi nedeniyle, çocukları "korunmaya muhtaç çocuk" olarak değerlendirerek aşıların uygulanmasına karar vermiştir. Neticede iç hukuk yollarını tüketmiş olan aile, Anayasa Mahkemesỉne bireysel başvuru yapmıştır.

AYM, başvuruyu, "özel hayata müdahale”, "tıbbi zorunluluklar ve kanunda sayılı haller dışında vücut bütünlüğüne dokunulamayacağı", "tıbbi müdahaleyi ret hakkı" ve "temel hak ve özgürlüklere müdahalenin sınırlandırılmasında kanunilik şartı” ilkeleri bağlamında dört temel başlık altında ele almıştır. Bu kararlarda AYM, Avrupa İnsan Hakları Mahkemesi ile paralel olarak özel hayat kavramını geniş yorumlar ve bu hakkın sadece mahremiyet hakkına indirgenemeyeceğini, kişinin vücut bütünlügüne ilişkin hukuksal çıkarının da özel hayata saygı hakkı kapsamında güvence altına alındığını vurgular. Ve Anayasanın 17. maddesini merkeze alır. Anayasa'nın 17. maddesinin 2. fikrası gereği; tıbbi zorunluluklar ve kanunda yazılı hâller dışında kişinin vücut bütünlüğüne dokunulamaz ve rızası olmadan bilimsel ve tıbbi deneylere tabi tutulamaz. Anayasa Mahkemesinin konuya ilişkin kararlarında vurguladığı üzere; özel yaşam (ya da mahremiyet) hakkı, gerek kamusal makamların gerek özel hukuk kişilerinin fiziksel ve ruhsal bütünlüğe yönelik saldırılarına karşı bireyleri korur ve söz konusu hukuksal çıkar, tıbbi müdahaleyi ret hakkını da içerir. Anayasa 17. madde gereği hastanın rızası olmaksızın yapılacak tıbbi müdahalelerin hukuka uygunluğunu sağlayan hâllerden biri tıbbi zorunluluk diğeri de kanuna dayanmasıdır. Mahkeme ise tıbbi zorunluluk kavramını; "hastanın rizasının alınmasının mümkün olmadiğı ancak müdahalede bulunulmaması durumunda telafisi güç zararların doğacağı ve çoğu zaman hastanın yaşamını yitirmesinin söz konusu olacağı durumlar" șeklinde tanımlamiştır (14)

\section{Anayasa Mahkemesinin Zorunlu Aşı ile İlgili Kararlarının Değerlendirilmesi: Yasal Dayanak- tan Yoksunluk}

Sonuç olarak Türk Anayasa Mahkemesi bu kararlarında, yasal dayanaktan yoksun olduğu temel gerekçesiyle aşıya zorlamanın bireysel hak ihlali olduğuna hükmetmiştir. O halde Anayasa Mahkemesi, Avrupa İnsan Hakları Mahkemesi’nin de aradığ koşul olan yasal dayanağın Türk hukuk düzeninde bulunmadığı kanaatine nasıl varmıștır şimdi bunu inceleyelim.

Türk Anayasa Yargısının çocukluk dönemi zorunlu aşı uygulamaları ile ilgili kararları değerlendirildiğinde; bu aşılar konusunda tıbbi zaruret halinin bulunmadığı tespitinin yanında merkezde "yasallık" tartışması yer almaktadır. Hatırlanacağı üzere; 17. maddenin ifadesinden; bir kimseye rızası dışında tıbbi bir müdahale -yaşam ve vücut bütünlüğü hakkına saldırı teșkil ettiğinden- ancak tıbbi zaruret halinde ve kanunda yazılı hallerde mümkündür. Bir tıbbi müdahale olan aşı uygulamasının da tıbbi müdahalenin genel şartlarına dolayısıyla rıza şartına uygun yapılması gerekmektedir. Rıza koşulu aranmadan aşı yapılması içinse yasal bir dayanak bulunmalıdır (15). Türk hukukunda konuyu aşılar özelinde düzenleyen yasal hükümler 1930 tarihli ve 1593 sayılı Umumi Hıfzısıhha Kanunu'nun (UHK) 57, 64, 72, 87 ve 89 . maddelerinde işlenmiştir.

Umumi Hifzıssıhha Kanunu'nun yukarıda zikredilen maddelerinden olan 57'de belirli hastalık türleri sayılmaktadır.

1593 Sayılı Umumi Hıfzısıhha Kanunu 57. madde: 
Kolera, veba (Bübon veya zatürree şekli), lekeli humma, karahumma (hummayi tiroidi) daimi surette basil çıkaran mikrop hamilleri dahi - paratifoit humması veya her nevi gıda maddeleri tesemmümatı, çiçek, difteri (Kuşpalazı) - bütün tevkiatı dahi sari beyin humması (İltihabı sahayai dimağii şevkii müstevli), uyku hastalığı (İltihabı dimağii sari), dizanteri (Basilli ve amipli), lohusa humması (Hummai nifası) ruam, kızıl, şarbon, felci tıfli (İltihabı nuhai kuddamii sincabii haddı tifli), kızamık, cüzam (Miskin), hummai racia ve malta humması hastaliklarmdan biri zuhur eder veya bunlarm birinden şüphe edilir veyahut bu hastalılardan vefiyat vuku bulur veya mevtin bu hastaliklardan biri sebebiyle husule geldiğinden şüphe olunursa aşağıdaki maddelerde zikredilen kimseler vak'ayı haber vermeğe mecburdurlar. Kudurmuş veya kuduz şüpheli bir hayvan tarafindan isırılmaları, kuduza müptela hastalarm veya kuduzdan ölenlerin ihbart da mecburidir.

72. maddede, 57'de zikredilen hastalıklardan birinin ortaya çıkması veya ortaya çıkmasından şüphe edilmesi durumunda bir kısım tedbirlere başvurulacağı belirtilmiştir. Söz konusu tedbirler arasında hastalara veya hastalığa maruz bulunanlara serum veya aşı uygulanması şeklindeki tedbire de yer verilmiştir. Ancak bireysel şikâyete konu somut olaylarda 57. maddede sayılan hastalıklar söz konusu değildir. Bu durumda 72. madde hükmü, başvuruya konu uygulamanın kanuni dayanağı olarak kabul edilemeyecektir.

72. madde şu şekilde düzenlenmiştir:

“57'nci maddede zikredilen hastalıklardan biri zuhur ettiği veya zuhurundan şüphelenildiği takdirde aşağıda gösterilen tedbirler tatbik olunur:

(1) Hasta olanların, hasta olduğundan kuşkulanılanların ve hastalığı taşıyıp yaydığı teknik inceleme ile belirlenenlerin, tekniğin gerektirdiği süre boyunca evlerinde veya sağlık ve teknik koşullara sahip yerlerde sağlık memurları tarafından tecrit ve gözetim altında tutulmasi,

(2) Hastalara veya hastaliğa yakalananlara serum veya așı uygulanması,

Mahkeme; Umumi Hıfzıssıhha Kanunu'nda mecburi bir aşı olarak sadece çiçek aşısının öngörülmek- te olduğu, bunun dışındaki aşı uygulamasının Bakanlığın ilgili genelgesi kapsamında ve belirlenen program çerçevesinde yapıldığ görülmekle birlikte genel ve zorunlu aşı uygulamasına dayanak oluşturacak bir kanun hükmünün mevcut olmadığg değerlendirmesini yapmıştır. Sonuç olarak Anayasa Mahkemesi, zorunlu aşı uygulamasının bedene müdahale olduğunu, ancak Anayasanın 17. maddesinde yer alan tıbbi zorunluluk ve kanuni dayanağ olmadığından bu uygulamanın zorla yapılmasının "maddi ve manevi varlığın korunması ve geliștirilmesi hakkının" ihlali niteliğinde olduğuna karar vermiştir $(14,16)$.

Ayrıca Mahkeme, Bakanlık Genelgesi ve belirlenen program çerçevesinde yürütülen aşıların yasal dayanağı olmadığından ebeveyn tarafından reddedilmesi durumunda çocuğun 5395 sayılı Kanuna göre de korunmaya muhtaç çocuk olarak kabul edilemeyeceğini, mahkeme kararıyla uygulanan sağlık tedbiriyle çocuğun vücut bütünlüğüne yapılan müdahalenin kanunilik şartı olan öngörülebilirlik unsurunu da taşımadığını ortaya koymuştur (17).

\section{Yasal Dayanak Var Mı Yok Mu? Tartışması}

Anayasa Mahkemesinin bu kararlarındaki içtiha$\mathrm{d}_{1}$ çeşitli eleştirilere uğramıştır. Bu eleştirilerin gerekçelerinden biri, kararlarda halk sağlığı ve çocuğun üstün menfaatinin geri plana itildiğidir. Kişi özerkliği ile kamu/halk sağlığ çatışmasının somutlaştığ 1 özel bir örnek olan çocuklara yönelik zorunlu aşı uygulaması, kuşkusuz veli ya da vasilerin çocuklarına yönelik velayet haklarını sinırlamaktadır. Bununla birlikte bu sınırlamayı, bulaşıcı hastalık riskinin tehdit ettiği diğer çocukların yaşam ve sağlık hakkı, çocukların korunmasına ilişkin anayasal yükümlülükler ve tarafı olduğumuz Çocuk Hakları Sözleşmesỉnin çocuğun üstün yararının korunmasına dayalı yaklaşımı karşısında koruyucu bir sağlık önlemi olarak değerlendirmek daha uygun olurdu $(2,17)$. Buna karşın zorunlu aşı uygulamasını, "birey özerkliği”" ve “toplum yararı” kavramlarını karşı karşıya getirerek tartışmanın sağlıklı bir yöntem olmadığı ve toplum yararının, bireyin özerklik alanına müdahaleyi tek başına meşru kılmayacağı yönünde yukarıdaki satırlardaki eleştiriye karşı argüman olarak nitelenebilecek 
görüşler bulunmaktadır (14).

Oy çoğunluğu ile alınan Anayasa Mahkemesi kararına katılmayan yargıcın karşı oy görüşünde de; zorunlu aşı uygulaması getirilebilmesi için ilgili mevzuattaki düzenlemelerin yeterli olduğu iddia edilerek karara muhalefet edilmiştir. Buna göre herkesin sağlıklı bir şekilde yaşamını sürdürmesini sağlamak devlete Anayasa tarafından verilmiş bir görevdir ve Umumi Hıfzısıhha Kanunu'nda bunu sağlamaya yönelik açık ve belirli düzenlemeler bulunmaktadır. $\mathrm{Bu}$ nedenle devletin görevlerinin bir parçası olarak zorunlu aşı uygulaması hukuka aykırılık oluşturmaz (18).

Anayasa Mahkemesi, bu davalarda verdiği kararlarda UHK 57'nci maddede sayılan hastalıkları sınırlı sayıda kabul etmiş ve madde 64'ü görmezden gelmiştir. Oysa 64. madde, 57'de sayılmayan herhangi bir hastalık, 'salgın' bir hastalığa dönüştüğü veya salgına dönüşme şüphesi bulunduğu takdirde Sağlık Bakanlığı'na o hastalığı bildirimi zorunlu hastalık olarak ilan etme ve bu kanunda sayılan tedbirlerin bir kısmını ya da tamamını uygulama yetkisi vermiştir (19).

Madde 64 - " 57 'nci maddede zikredilenlerden başka her hangi bir hastalık istilai şekil aldı̆̆ı veya böyle bir tehlike baş gösterdiği takdirde o hastalı̆̆ın veya her hangi bir hastalık şeklinin memleketin her tarafında veya bir kısmında ihbarı mecburi olduğunu neşrü ilâna ve o hastalğga karşı bu kanunda mezkür tedabirin kaffesini veya bir kısmını tatbika Sıhhat ve İçtimai Muavenet Vekaleti salahiyettardır."

Anayasa Mahkemesinin karşı oy görüşünde ileri sürüldügü gibi; zorunlu aşılar konusunda Türk Hukuk düzeninin kanunilik koşulunu karşıladığına yönelik doktrinde de görüşler mevcuttur. Bu görüş gereği; UHK 64. madde dışında idare, bu kanunda ayrıca ve açıç̧a gösterilmeyen haller ve hastalıklar bakımından aşı uygulama yetkisine sahiptir. Zira "Medeni Kanunun 24’üncü maddesinin ikinci fikrası gereğince "üstün nitelikte kamusal yararın bulunması" halinde kişilik hakkına müdahale edilebilmesi, 1593 sayıl Umumi Hıfzısıhha Kanununda ve 663 sayılı Sağlık Bakanlı̆̆ı ve Bağh Kuruluşlarının Teşkilat ve Görevleri Hakkında Kanun Hükmünde Kararname” de genel sağlığın korunmasına yönelik olarak verilen yetkiler, idarenin aşı uygulama yetkisini de içeren tedbirlere başvurabileceğini göstermektedir. Dolayısıyla idarenin genel sağlığı korumak amacıyla aşı uygulama yetkisi kanuni dayanaktan yoksun olmamakla, Anayasa Mahkemesinin rıza dışı aşı uygulamada hak ihlali bulunduğuna yönelik kararları uygun bulunmamaktadır (1).

Anayasa Mahkemesi'nin belirlemesi ise 'Sağlık Bakanlığı ve Bağlı Kuruluşlarının Teşkilat ve Görevleri Hakkında Kanun Hükmünde Kararname’nin, Anayasa’nın ikinci kısmının ikinci bölümünde yer alan temel bir hakka yönelik sınırlandırma ve müdahale niteliğinde olması açısından dayanak kabul edilemeyeceğidir (4). Ancak 663 sayılı Sağlık Bakanlığı ve Bağlı Kuruluşlarının Teşkilat ve Görevleri Hakkında Kanun Hükmünde Kararnamenin yerine daha sonradan 1 sayılı Cumhurbaşkanlığı Teşkilatı Hakkında Cumhurbaşkanlığg Kararnamesi (md. 361) ve buna bağlı olarak çıkarılan kanun altı düzenlemeler gibi genel nitelikteki hükümler getirilmiştir. Lakin söz konusu yasal dayanak yetersizliğinin bu şekilde doldurulmuş sayılamayacağ yani; yeni düzenlemenin de bir kanun hükmünde kararname olmasından buna karşın Anayasa’nın 13. maddesine göre bir temel hak ve özgürlüğün -olağan dönemlerde- Cumhurbașkanlığ Kararnamesi ile s1nırlandırılamayacağından kaynaklanmaktadır (19).

Mahkeme aşılama tıbbi müdahalesinin kanunilik şartını taşıyıp taşımadığına ilişkin incelemesinde; temel hak ve hürriyetlerin sınırlandırılmasına ilişkin kanunların şeklen varlığının yeterli olmadığını, kanunun maddi içeriğinin de kanunun niteliği bak1mından önem kazandığını belirtmektedir.

Mahkeme kanuni niteliği;

- vatandaşların belirli bir olaya uygulanabilir nitelikteki hukuk kurallarının varlığı hakkında yeterli bilgiye sahip olabilmesi,

-ilgili normun keyfiliğine karşı bir koruma sağlamasi,

-yetkili makamlara verilen yetkinin genişliğinin ve icra edilme biçimlerinin yeterli nitelikte tanımlanması olarak ifade etmektedir.

Böylece kanunilik ilkesi gereği; kişinin aşıyı reddetmesi durumunda uygulanacak olan okula kaydının 
yapılmaması ya da salgın sırasında okuldan uzaklaştırılması gibi yaptırımlara ilişkin usuller açıkça belirtilmiş olmalıdır (17).

II. COVID-19 Așılamalarının Zorunlu Tutulması Olasılığı Karşısında Türk Hukuk Düzeni Açısından Uygunluğunun Tartışılması

Şimdi de Umumi Hıfzısıhha Kanunu’nun genel bir aşı yükümlülüğü için yetkilendirme içermese de klinik olarak ağır seyreden bulaşıcı salgın bir hastalık ortaya çıkarsa, nüfusun tehdit altında olan kesimi için koruyucu aşılamaya katılma zorunluluğu getirilebileceği yönündeki görüssleri de dikkate alarak bu hususları COVID-19 aşıları açısından değerlendirmeye geçelim. O halde COVID-19 bir pandemi salgını olduğuna göre UHK/64. maddede ön görüldüğü üzere 72. maddede öngörülen tedbirlerden olan aşılama zorunlu tutulabilir mi? Ancak bunun öncesinde bireyin fiziksel bütünlüğü başta gelmek üzere haklara meşru bir müdahalenin; elverişlilik, gereklilik ve orantılılık kriterleri ile incelemesini yapabiliriz (20).

Elverişlilik: Aşılar, bulaşıcı bir hastalıkla mücadele amacıyla sağlıklı kişilere ulaşmasını engellemeye yönelik koruyucu bir tıbbi tedbirdir. Bu bağlamda aşı olma endikasyonu olduğu halde aşılanmayan -çocuklar dahil- herkes, aşılanmamış hassas grupların hastalık riskini artıracağ 1 , hatta aşılanmaya uygun olamayan nüfusun savunmasız kesimlerinin yaşam hakkını tehdit ettiği tespiti yapılabilir (21).

Bu durumda halihazırda korona virüse karşı daha etkin bir koruyucu önlem -ya da tedavi edici etkili bir antiviral- henüz bulunamadığından, insan sağl1ğına zarar vermemek koşulu ile COVID-19 virüsüne karşı geliştirilen aşıların, halk sağlığını korumak için elverişli bir yöntem olduğu söylenebilir. Ancak bunu söyleyebilmek için de aşının zorunlu olduğu popülasyonda halk sağ lığı hedefine ulaşmak için etkili bir araç olduğunu gösteren veriler mevcut olmalıdır. Başkalarına zarar gelmesini önlemek için zorunlu aşılamanın gerekli olduğu düşünülüyorsa örneğin aşıların bulaşma zincirlerini kesmekte ve ciddi enfeksiyon ve/veya bulaşmayı önlemede etkili olduğuna dair yeterli kanıt bulunmalıdır. İzin verilen aşının temini yeterli ve güvenilir olmalı ve zorunlu hale getirileceği kişiler için makul, ücretsiz erişime sahip olmalıdır. Yeterli arzın ve makul, ücretsiz erişimin olmaması, aynı zamanda aşılanması gereken ancak aşıya erişemeyen kişiler üzerinde külfet yaratacak ve sağlik hizmetlerine erişimde sosyal eşitsizliği şiddetlendirebilecektir.

Etkinlik bağlamında aşı güvenliği de dikkate alınacak bir unsurdur. Aşı zorunlu yapılacak ise güvenilir olduğunu kanıtlayan veriler mevcut olmalıdır. Güvenlik verileri eksik olduğunda veya aşı ile ilişkili risklerin, aşı olmamaktan daha ağır bastığı düşünüldüğünde zorunlu aşıyı bu temelde haklılaştırmak mümkün olmayacaktır. Acil veya şartlı kullanım için izin verilen aşıların güvenlik eşiğini karşılayıp karşılamadığı özellikle değerlendirmelidir.

Yeterli güvenlik kanıtının yokluğunda, zorunlu aşılamanın halk sağlığını koruma hedefine ulaşacağının garantisi olmayacaktır. Aşı yeterince güvenli kabul edilse bile, aşıyla ilgili oluşabilecek zararları ele almak için kusursuz (objektif sorumluluk) tazminat planları ile zorunlu aşılama uygulanması önerilmektedir. Çünkü aşıya bağlı zarar gören kişilerin zorunlu müdahaleden kaynaklanan zararlardan dolayı yasal çare aramasını talep etmek adaletsiz olacaktır (22).

COVID-19'a karşı aşı araştırma-geliştirme çalışmaları, dünya genelinde daha önce görülmemiş bir hız ve ölçekte gerçekleşmiştir. COVID-19 aşılarının ne kadar süre bağışıklık sağlayacağı ve uzun dönem yan etkilerinin ne olacağı şu an için kesin olarak bilinememektedir. Aşıların uzun süreli bağışıklık sağlayıp sağlayamayacağı, virüsün sık mutasyona uğraması halinde -influenz aşılarında olduğu gibi- her yıl yeni mutant suşlara göre yeniden üretilmesi ve toplumun her yıl yeniden aşılanması gerekip gerekmeyeceği netleşmiş değildir. Bu ise aşının hem tüm topluma uygulanabilirliğini zorlaştıracak hem de maliyetlerde ciddi bir artışa yol açacaktır. Aşıların "uzun dönem güvenlilik" bakımından değerlendirileceği Faz 4 aşamasına gelebilmesi için normal şartlarda birkaç yıl gerektiği göz önüne alındığında; Faz 3 aşamasını geçen/geçecek COVID-19 aşılarının Faz 4 sürecinde gelişen yan etkilerinin tespit ve takibi için gelişkin ve etkin, şeffaf bir sürveyans sisteminin varlığı önemlidir. (23). 
12 yaş altı çocuklar için COVID-19 aşılarının güvenliği ve etkinliğine ilişkin henüz yeterli veri eksikliği nedeniyle bu yaş grubu aralığının okula kabulünü aşı olma ön koşuluna bağlamak, etik açıdan da tartışmaya açıktır(24).

Şunu da belirtelim ki; yetkili COVID-19 aşılarının, hastalığın ağır seyri ve ölümleri önlemede güvenli ve etkili olduğu ve aşı arzının adaletsiz de olsa küresel olarak artmaya devam edeceğini açılayan Dünya Sağlık Örgütü’nün, etik gerekçelerle bu aşıların zorunlu uygulanmasına mesafeli durduğu anlaşılmaktadir.

Gereklilik: Gereklilik kriteri, meşru amaca ulaşabilmek için söz konusu müdahalenin acil bir ihtiyaca cevap verecek son çare olması halinde karşılanmış olur. Buna karşın vücut bütünlüğü ve ebeveyn haklarını daha az sınırlandıran fakat amaca ulaşmada aynı derecede elverişli önlemler mevcut ise gereklilik kriteri karşılanmamış olacaktır. Başka bir deyişle, aşı yükümlülügü, daha yumuşak bir önlemle aynı amaca ulaşılamıyorsa zorunlu tutulabilir. Bu noktada aşının tavsiye edilmesi yumuşak müdahale örneği olarak akla gelebilir ve bu şekilde sürü bağışıklığı sağlanabilecekse aşıya zorlama meşru görülmeyecektir (20). COVID-19'un tedavisinde şu ana kadar etkili sonuç alınan başkaca bir yöntem bulunmayışı karşısında, zorunlu aşı tatbikinin gerekli bir müdahale olduğu söylenebilir. Asemptomatikten yaşamı tehdit edene kadar ciddiyet aralığ rına yönelik değişen tehdidi ve gelişen varyantları, aşılama zorunluluğu lehine bir argüman olabilir. Daha önce zorunlu aşllama programlarına konu olan birçok aşı, çocuklara yönelikti. Yine de, COVID-19 söz konusu olduğunda, bir grup olarak çocuklar enfeksiyona daha az eğilimli veya hafif veya asemptomatik versiyonlardan muzdarip görünüyor. Bu koşullar altında, amaç çocukları korumaksa, zorunlu aşılama çocuklar için gereklilik açısından tartışmalı hale gelmektedir (24).

Yaşamakta olduğumuz COVID-19 salgınını Dünya Sağlık Örgütü 11 Mart 2020'de Uluslararası Sağlık Tüzügü̈ne istinaden halk sağlığı acili olarak ilan etmiştir. Peki, COVID-19 salgını konusunda Dünya Sağlık Örgütünün almış olduğu "halk sağlığı acili" kararına dayanarak bu durumun tıbbi zorunluluk kapsamına girdiği iddia edilerek aşılamanın gerekliliği üzerinden zorunlu tutulabilir mi? Tekrar vurgulamak gerekir ise; Hasta Hakları Yönetmeliği’nin 24/8'inci maddesindeki "Hastanın rızasının alınamadığ ${ }_{1}$ hayati tehlikesinin bulunduğu ve bilincinin kapalı olduğu acil durumlar ile hastanın bir organının kaybına veya fonksiyonunu ifa edemez hale gelmesine yol açacak durumun varlığı halinde, hastaya tıbbi müdahalede bulunmak rızaya bağlı değildir." şeklindeki açıklama tıbbi zorunluluk halini tanımlamaktadır. AYM de tıbbi zorunluluk kavramını; "genel olarak hastanın rızasının alınmasının mümkün olmadığı, ancak müdahalede bulunulmaması durumunda telafisi güç zararların doğacağı ve çoğu zaman hastanın yaşamını yitirmesinin söz konusu olacağı halleri ifade etmek üzere kullanıldığı”"nı belirtmiştir. Tibbi zorunluluk kavramı yukarıda Anayasa Mahkemesi kararındaki ve Hasta Hakları Yönetmeliği 24/8'deki anlamda kabul edildiğinde tıbbi zorunluluk hali salgin hastalık dönemi bile olsa - COVID-19 pandemisi için de- her zaman gerçekleşmeyebilir (5). Zira aşı önleyici bir tıbbi müdahale olmakla bireysel düzeyde tıbbi aciliyet koşulu gerçekleşemez.

Orantılılık: Orantılılık ilkesi çerçevesinde, vücut bütünlügü ve ilgili haklara getirilen sınırlandırmada öngörülen meşru amaç ile sınırlandırma vasıtası arasinda uygun bir denge kurulmalıdır. Bireyin fedakarlığının ağırlı̆̆ 1 göz önünde tutulmalı ve kamunun menfaati ile bireyin menfaati arasında adil bir dengenin kurulup kurulmadığı belirlenmelidir. Bu noktada yaşanmakta olan salgın hastalığın toplumdaki etkisi, toplumda yayılma durumu, ölüm oranları, kişileri yoğun bakıma düşürme oranları gibi bazı somut kriterlerlerden elde edilecek verilere göre müdahalenin orantılı olup olmadığ alınır (20).

Ancak aşılanan kişinin yaşam ve vücut bütünlügü hakkına yapılan müdahalenin yaratabileceği olası zararlar (aşının yan etkileri) ile başkalarının sağlık ve yaşamının korunması amacı arasında yarar-zarar dengesini öngörmek kolay değildir. Burada zorunlu aşı, bireyin yaşam ve vücut bütünlüğü hakkı bakımından düşük de olsa bir risk ortaya çıkarırsa, ana- 
yasal hakkın ihlal edildiğinden söz edebilmeli miyiz yoksa kamunun esenliği için bireysel riskler göze alınabilecek midir? Avrupa İnsan Hakları Mahkemesi’ne (AİHM) göre de bu tür müdahaleler kişinin sağlığına zarar vermediği sürece haklıdır. Toplum sağlığının korunması amacını taşıyan aşı uygulamasının, ilgili kişinin sağlığı ve hayatı bakımından bir tehlike yaratmaması koşuluyla, demokratik bir toplumda gerekli, amaçla orantılı bir tedbir olduğunu kabul etmek gerekir (5).

Müdahalenin orantılı olması için gereken bir diğer koşul, onun demokratik bir toplumda gerekli olmasıdır. Örneğin gönüllü aşılanma oranlarının halihazırda yüksek olduğu toplumlarda böyle bir müdahale gerekliliğini kaybedecek ve orantısız olarak nitelendirilebilecektir. Bu koşullara sahip toplumlarda çeşitli tavsiye ve teşviklerle halk sağlığının korunması daha kolay gerçekleşecektir. Genel popülasyonda yaygın gönüllü aşılama ve farmasötik olmayan müdahaleler gibi, COVID-19 ile etkili bir şekilde mücadele edebilecek zorlayıcı olmayan alternatif müdahaleler, COVID-19’a karşı aşılanmayı zorunlu kılmadan tıbbi bakım sağlayanlardan geçecek enfeksiyonları azaltmak dahil herkese daha büyük fayda sağlayacaktır (7).

$\mathrm{Bu}$ adil dengenin kurulabilmesi için öncelikle müdahale edilen hakkın özüne dokunulmamalıdır. Örneğin bu bağlamda kolluk marifetiyle insanları zorla yakalayıp aşı vurmak, orantısız bir müdahale olabilir. Fakat aşı uygulamasını kanuni düzenlemeyle zorunlu tutup, uyulmadığı takdirde -etkili itiraz yolları açık olmak kaydıyla- çeşitli yaptırımların uygulanması, orantılı bir müdahale kabul edilebilir.

III. COVID-19 Aşı Uygulamalarının Zorunlu Tutulması Olasılığının Karşılaştırmalı Hukukla Birlikte Kısa Bir Değerlendirmesi

Geçen yıl Vaccine (Aşı) da yayınlanan ve 193 ülkeyi kapsayan 'Ulusal zorunlu aşılama politikalarının küresel değerlendirmesi ve uyumsuzluğun sonuçları’ başlıklı bir çalışma, 100'den fazla ülkenin bir tür zorunlu aşılama politikasına sahip olduğunu tespit emiştir. Bazı ülkelerde, belirli aşıları olmayan çocukların okula gidemediği ve/veya ebeveynlerinin para cezasına ve hatta hapis cezasına çarptırıldığı ölçüde 'zorunlu' görülebilecek aşı politikaları vardır. Brezilya'da Yüksek Mahkeme, COVID-19 aşısını zorunlu hale getirmenin yasal olduğuna karar verirken; vatandaşların, idari kolluğun fiziki güç uygulaması yoluyla aşı yaptırmaya zorlanamayacağına hükmetmiştir. Hükümetlerin kendi içinde bile anlaşmazlıklar dikkati çekmektedir. Bazı hükümet görevlileri 'aşılı ve aşısız ayrımı yapmak zorunlu aşı ile aynı olacaktır' derken; kimileri de bunun 'aşılanan kişilerin haklarını tekrar kullanabilmeleri için gerektiğini' söyleyerek karşı fikri savunmaktadır. İkinci görüşe katılan İsrail devletinde aşı olduğunu kanıtlayabilenlerin spor salonlarına, otellere, konserlere ve restoranlara girmelerine, ülkeler arasinda seyahat etmelerine izin verilerek aşılılara ayrıcalık tanınmaya başlanmıştır. Bazen de aşı yaptırmış olanlara, örneğin sokağa çıkma yasakları gibi kimi yasak ya da kısıtlamalardan muaf tutulma gibi ayrıcalıklar tanınabilmektedir. Başlangıçta sağlık çalışanları için COVID-19 aşılarını zorunlu kılma olasılığını tartışan İsviçre hükümetinin bu tasarısı; Ulusal Biyomedikal Etik Danışma Komisyonunun muhalefeti ile karşılaşmıştır. Komisyon, ortaya çıkması muhtemel yasal sorunları önceden haber vererek, COVID aşılarının bulaşmaya karşı koruma sağladığı kanıtlanmadıkça ve herkes tarafından erişilebilir olmadıkça hiçbir «aşı sertifikasının〉 düşünülemeyeceğine dikkat çekmiştir. Bu ifade bile örneğin: 'Aşının erişilebilir olarak değerlendirilmesi ücretsiz olması mı demektir?' ya da 'Hepsi' İsviçre sınırlarının ötesindeki insanları da içeriyor mu?' gibi bazı yorum sorunlarını gündeme getirmektedir (24).

Sadece bu birkaçörnekten, ulusal tercih ve hukuki düzenlemelerin tutarsız olduğu açıktır. Durum geliştikçe, aşılanmamış kişilerin haklarını kısıtlayan ülkeler tarafından alınan tedbirler devam edecek gibi görünmektedir ve bunlardan bazılarına mahkemelerde itiraz edilmesi kaçınılmaz bir durum olacaktır.

Bu ikilemi çözmenin bir yolu, 'zorunlu' ile ne anlaşıldığına bağlı olabilir. Yorum muhtemelen kime ve hangi ülkede sorulduğuna bağlıdır. Hiçbir devlet, vatandaşlarını fiziksel olarak kısıtlayacağını ve iğnelerin kollarına kolluk gücüyle zorla batırılacağını önermiyor ama bazı hükümetler, aşılılara belirli ay- 
rıcalıklar ve aşısızlar için yukarıda verilen birkaç örnekte olduğu gibi istisnalar tanımaya veya uygulamaya başlamıştır. Fiziki zorlama gündeme gelmese, hatta idari para cezası ya da okula kabul etmeme, aşı olmadıkça kamu görevinde bulunamama gibi zorlayıcı tedbirler olmaksızın gönüllü aşı olanları ödüllendirici ve ayrıcalık tanıyıcı düzenlemeler de dolaylı olarak aşıya zorlamak anlamına gelecek midir?

$\mathrm{Bu}$ arada, bir yandan hükümetler düzeyinde zorunluluk mu yoksa ikna yolu mu diye tartışılırken diğer yandan özel sektör kendi aşılama kurallarını oluşturmaktadır. Konuyu daha da karmaşık hale getiren, özel ve kamusal alanlar arasındaki ayrımın ve kontrolün bulanıklaşabilmesidir. Devlet tarafından uygulanan aşı yetkileri ile özel sektör ve işvereni tarafından zorunlu kılınan aşı yetkileri arasında ayrım yapmak önemlidir. Devletin hukuk düzeni düzeyinde aşı olma zorunluluğu getirilmemiş olsa dahi «özel şirketler, kime hizmet vereceklerini ve tesislerine kimlerin girebileceğini giriş koşulları olarak seçebilir (mi?)». Örneğin; seyahat şirketleri tatil hizmetlerini COVID-19 aşısı olanlar ile sınırlandırabilir mi? Özel şirketler tarafından verilen hizmetlerde, çalışanlara veya müşterilere yönelik, hizmetin alınmasının aşı yapılmasına bağlanması mümkün müdür? Esasen küresel düzeyde bu durumlar ile karşılaşılmaya başlanmıştır bile (24). Bu iki yönlü devlet-özel sektör yaklaşım farklılığı, tutarsız veya ayrımcı sonuçlar doğurma riski taşımaktadır: örneğin, özel bir hastanede çalışan bir sağlık personeli COVID-19 aşısı yaptırmak zorunda kalabilir ancak devlet hastanesindeki bir çalışan aynı yükümlülük altında olmayabilir. Özel aktörlere bu tür işlevler verildiğinde, özgürlüklerinin diğer temel haklarla tartılması ve buna göre sinırlandırılması gerekecektir. Bundan kaynaklı olası hukuki uyuşmazlıklarda mahkemeler özel kişiler arasındaki ilişkilere baktıklarında, hukuku temel haklara uygun olarak da uygulamak zorunda kalacaklar ve bu da ayrımcıllk yapmama ve diğer hakların dolaylı bir etkisine yol açacaktır (24).

Bir diğer örnek; işverenin, işyeri kapsamına giren yerlerde işçinin sağlığını ve hayatını korumak amacıyla COVID-19 aşısı yaptırılmasını zorunlu tutması halinde gündeme gelebilecek problemdir. Ülkemiz- de aşının zorunlu tutulabilmesi için yasallık ilkesini karşılayan bir dayanak olmadığı da hatırlandığında; normlar hiyerarşisi gereğince de kanunla düzenlenmeyen bir uygulamanın, Bakanlık Genelgesi ile getirilerek vücut bütünlügüne dokunulabileceğinden bahsetmek hukuka uygun düşmeyecektir. Bu bağlamda işverenin kendi işyeri kapsamında bu aşıyı zorunlu kılması, işçi bakımından bu aşının mutlaka yaptırılması gerektiği anlamına gelemeyecektir. İşçinin, Anayasa ile kendisine tanınmış bir hakkı olan vücut dokunulmazlığı hakkı, işveren tarafından ihlal edilemez. Bununla beraber işçinin aşıyı yaptırmamasının, işveren tarafından haklı fesih sebebi oluşturup oluşturmayacağı tartışmalı olup; işverenin koronavirüse karşı tüm tedbirleri alıp aşıyı da sağlamasına rağmen işçinin aşıyı reddedip hastalanması, hastalık bulaştırmasını, "iş güvenliğine aykırı”" ve İş Kanunu’na göre "geçerli fesih" nedeni sayılabileceğini ileri süren görüşler vardır (25).

Ayrıca zorunlu aşılamanın etik olarak izin verilebilir hatta zorunlu olduğu kabul edilse bile bu kabul, özellikle söz konusu aşı yeni olduğunda, zorunlu aşılamanın iyi bir kamu politikası olduğunu göstermez. COVID-19 aşılarının zorunlu tutulmasının, aşıya karşı muhalefeti arttıracağ 1 ve bilime güven kaybına yol açacağı gibi istenmeyen riskli sonuçlar taşıyabileceğini öne süren görüşler de dikkate değerdir. Azınlık, sırf azınlık olduğu için göz ardı edilmemeli ve eğer büyük bir azınlıksa, onu geçersiz kılmanın sosyal uyum ve demokrasi açısından etkilerine dikkat edilmelidir. COVID-19 aşlarının, diğer aşılara göre ne kadar hızlı geliştirildiği konusunda rahatsızlık duyan grubun kaygılarını göz ardı etmek hem etik olmayacak hem çoğulculuk ve demokrasi erdemlerine uygun düşmeyecektir.

Aşının kullanıma sunulması anlık olmayacaktır. Hükümetlerin dağıtım önceliklendirme planlarını (önce sağlık çalışanlarına, yaşlılara, diğer temel çalışanlara vb. erişim izni verilmesi) uygulamaya geçirmesi ile bu gruplardaki gönüllü aşılamaya yönelik talep, yeterince yüksek olabilir. Zamanla bu popülasyonlar başarılı olursa, diğerleri ikna olabilecek ve aşı olmayı seçebilecektir. Bunun aşılanmış kişilerin toplam sayısını sürü bağışıklığına ulaşmak için gerekli 
düzeye getirip getiremeyeceği, aşının ne kadar etkili olduğuna ve korumasının kalıcı olup olmadığına bağlı olacaktır. Devlet, hedefe ulaşmak için en az kısıtlayıcı araçları kullanır (6).

Evet, tarihsel olarak zorunlu aşılama politikaları, özellikle sağlık ve eğitim ortamlarında gönüllü politikalardan kaynaklanan düşük aşı alımı yüzünden yakın bir tehdit oluşturan salgınlar nedeniyle acil durumlarda daha yaygın olarak kabul görmüștür. Aş1 politikası yelpazesinin bir ucunda daha az kısıtlayıcı seçenekler -gönüllü tavsiyeler vb.- vardır. Diğer uçta ise daha kısıtlayıcı seçenekler - yasal ve mali cezalarla desteklenen zorunlu emirler, uyulmaması potansiyel olarak hapisle sonuçlanmak- yer bulur. Bu noktada, COVID-19 aşısını zorunlu kılmak için ilgili emsaller mevcut olsa dahi halk sağlığı alanında da etik ilkeler, yetişkinlerde zorunlu aşılama politikalarının genellikle 'son çare' olması gerektiğini önermektedir (7).

COVID-19 aşılama programları, ancak mevcut aşıların güvenli ve etkili olduğuna ve bunların dağıtımına öncelik verilmesine yönelik politikaların adil ve kanıta dayalı olduğuna dair yaygın bir inanç varsa başarılı olacaktır. Bu nedenle tarafsız bilim insanlarına, hükümetlerin tarafsız uzman danışmanlarına ve aşıyla ilgili faaliyetlerinin şeffaf süreçlerine güvenin sağlanması COVID-19 aşılarına dair yüksek umutların gerçekleşmesinde etken olacaktır (26).

\section{SONUÇ}

Gerek Avrupa İnsan Hakları Mahkemesi gerek Türk Anayasa Mahkemesi’nin konuyla ilgili kararlarında da belirlendiği üzere; bir hak ya da özgürlüğe müdahale söz konusu olduğunda müdahalenin hukuki bir temelinin yani müdahaleye yetki veren bir kanun hükmünün mevcut olması öncelikle aranan koşuldur. Kişinin rızası olmaksızın uygulandığı takdirde COVID-19 aşı uygulamaları da diğer zorunlu tutulan aşı uygulamalarında olduğu gibi Anayasa ve Avrupa İnsan Hakları Sözleşmesi'nde düzenlenen bazı temel hak ve özgürlüklere müdahalede bulunacaktır. Bu hak ve özgürlükler arasında, vücut ve beden bütünlügüne müdahale, ebeveynin velayet hakları, çalışma hakları gibi haklar sayılabilir. Nitekim Türk
Anayasa Mahkemesinin içtihatları, zorunlu aşılar hakkında Türk hukuk düzeninde hak ve özgürlüklere müdahaleyi hukuken meşru kılabilecek yasal bir dayanağın bulunmadığı yönünde olmuştur. Bulaşıcı ve salgın hastalıklarda alınacak tedbirleri ve yetkileri düzenleyen en temel kanun düzeyindeki hukuki düzenleme olan Umumi Hifzısihha Kanunu'nun mevcudiyeti, Anayasa Mahkemesi kararlarından anlaşılacağ anlamına gelmemektedir. Anayasa Mahkemesinin kararları, çeşitli yönlerden eleştiriye uğramıştır. Esasen karşı oy gerekçesinde de vurgulandığ 1 ve doktrinde de destekleyici görüşlerin olduğu, yürütmenin de dayandığ UHK.64. maddesinin, 57. maddede sayılanlar dışında ortaya çıkacak başka salgın hastalıklarda da kanunun yetki verdiği aşı uygulamalarının zorunlu tutulabilmesine imkân verdiğidir. Bu yorum ilk bakışta prima facie doğru görünmekle birlikte Anayasa Mahkemesi kanunların şeklen var olmasının yeterli olmadığını, kanunilik ölçütünün aynı zamanda maddi bir içeriği de gerektirdiğini vurgulamaktadır. Kanunla sınırlama ölçütü, öngörülebilir ve belirli olması halinde kişinin hukuku bilmesine yardımcı olacağı gibi uygulayıcının keyfî davranışlarının önüne geçebilecektir. Anayasảnın 2. maddesinde yer alan hukuk devletinin temel ilkelerinden olan belirlilik ve öngörülebilirlik yalnızca yasanın uygulanmadan önce sunulması anlamına gelmez aynı zamanda hukuka tabi kişilerin davranışlarını kendisine uygun biçimde düzenleyebilmesi için yeterli hassasiyet, açıklık ve netlikle, anlaşılır şekilde formüle edilmiş olması gerekir. Aksi takdirde bireylerin yaptıkları işlemlerinin sonuçlarına ilişkin hiç tahmin dahi edemedikleri sonuçlarla baş başa kalmaları hukuk güvenliğini sarsacaktır. Belirlilik ilkesi icabı birey, belirli bir kesinlik içinde, hangi somut eylem ve olguya hangi hukuksal yaptırımın veya sonucun bağlandığını, bunların kamu otoritesine hangi müdahale yetkisini doğurduğunu, kanundan öğrenebilme imkânına sahip olmalıdır. Birey ancak bu durumda kendisine düssen yükümlülükleri öngörüp, davranışlarını düzenleyebilir (30). $\mathrm{Bu}$ nedenle aşının zorunlu veya tavsiye niteliğinde olmasına göre, kişinin aşıyı reddetmesi durumunda 
uygulanacak olan okula kaydının yapılmaması ya da salgın sırasında okuldan uzaklaştırılması gibi yaptırımlara ilişkin usuller de yasa ile açıkça belirtilmelidir (17). Oysa COVID-19 pandemi salgını ile mücadelede geliştirilen aşıların olunması zorunlu tutulduğu takdirde, buna uymayanların ne tür yaptırımlarla karşılaşabileceğine dair UHK'da yaptırımlar gösterilmiş değildir.

Yapıldığ 1 dönem itibariyle oldukça başarılı sayılsa da 1930 tarihli Umumi Hıfzısıhha Kanunu bugün için anlaşılması güç olup, idarenin genel sağlık alanındaki yetkilerinin günümüz koşullarına uygun şekilde kanunla yeniden düzenlenmesi gerekmekte$\operatorname{dir}(1)$.

Yine de şunu hatırlatmak gerekir ki; Avrupa İnsan Hakları Mahkemesi kararlarında işaret edildiği şekliyle, bulaşıcı ve salgın hastalıklarla mücadelede -kanun-ile düzenlenmiş olmak kaydı ile meşru amaç yani kamu sağlığını korumak için demokratik bir toplumda, ölçülü ve orantılı olarak bireysel hakların kullanımına devlet tarafindan sınırlayıcı müdahaleler getirilebilir. Ancak COVID-19 aşıları için olumlu pek çok veri olsa da, aşı karşıtlığına müracaat etmeden aksine bilime güveni de korumak adına; meşru amaç kriterlerinden gereklilik ve elverişlilik ölçütleri ile değerlendirildiğinde de zorunlu tutulması sakıncalar taşımaktadır. Önce zarar vermeme etik prensibi gereği aşıların etkinliği ve güvenliği açısından geri bildirimler izlenmeli, şeffaflık sağlanmalıdır.

Bir aşının kullanıma hazır hale gelmesi ortalama 10-15 yıl sürmektedir. Örneğin hızlı geliştirildiği kabul edilen aşılardan olan kabakulak aşısının geliştirilmesi 4, çocuk felci aşısı yedi yıl, kızamık aşısı dokuz yılı bulmuştur. Ancak daha önceden Şiddetli Akut Solunum Sendromu [Severe Acute Respiratory Syndrome (SARS)] ve Orta Doğu Solunum Sendromu [Middle East Respiratory Syndrome (MERS)] ile ilgili yapılan aşı çalışmaları, Covid 19 aşılarının geliştirilmesi sürecini büyük ölçüde hızlandıran unsurlardan biri olmuştur (27). Viral proteinin sekans kodunu çözülmesi, yeni jenerasyon aşı çalışmalarını hızlandırmaktadır.

Aşıların klinik araştırmaları bakımından $3 \mathrm{faz}$ bulunmaktadır: Faz 1, yirmi ila yüz sağlıklı gönüllü- de ilacın vücut işleyişine etkisini belirlemek amacıyla sağlıklı bireylerde eğer mümkün değilse hasta gönüllülerde ilacın/aşının denenmesini kapsayan klinik araştırma aşamasıdır. 2. Faz çalışması daha geniş sayıda insan denekleri üzerinde (yüz ila beşyüz) uygulanır. Bu fazda, aşının tehlikeli yan etkileri yanında, bağışıklık sistemini harekete geçirmesi gözlemlenir ve bunun için de beklemek gerekir. Çalışmaların en kritik evresi olan 3. Faz çalışmalarına ise, aşı yan etkileri ve etkinliğinin kontrolü için ilk iki faza kıyasla çok daha geniş ölçekli, 10.000-30.000 gönüllü kişi dahil edilmektedir ki COVID-19 aşılarında bu sayının 40.000 olduğu söylenmektedir. Bunun için de yine uzun bir süre beklemek gerekmektedir. Bu bekleme süresi normal şartlarda 4-5 yılı bulabilse de içinde bulunduğumuz pandemi sürecinde, aşı araştırmalarının faz çalışmaları on sekiz ay gibi bir sürede tamamlanmıştır. Nihayet üçüncü fazı başarı ile tamamlayan aşılar, yaygın kullanım için sağlık otoritelerine başvurabilir duruma gelir. Ancak aşılar sağlık otoritelerince kullanım izni alsalar bile, güvenlik ve etkinlik süreçleri bitmez. Dördüncü faz adı verilen çalışmalar ile aşının etkililiği, olası uzun dönem veya nadir yan etkilerinin takibi, aşı büyük kitlelere uygulanırken de devam eder $(28,29)$.

FDA yani ABD Gıda ve İlaç Dairesi, 23.08.2021 tarihi itibarıla Pfizer-BioNTech aşısına tam onay vermiş ise de bir kısmı henüz 2.Faz aşamasında ya da 3.Fazda bulunan COVID-19 aşı adayları da klinik araştırmalarını sürdürmektedir. Bunlar arasında Türkiyede üretilmiş Türkovac gibi yerli aşı adayları da bilinmektedir (31). Lakin halihazırda ülkemizde uygulanan ve yapılan bildik aşıların, acil kullanım onayı almakla artık Faz 3 aşamasını geçtiği ve Faz 4'te olduğunu kabul edebilir miyiz yoksa pandemi koşullarının hızını düşünerek aslında bu uygulanmakta olan aşılar için yine de Faz 3 'ün içerisinde olduğumuzu mu kabul daha uygundur? Kimi görüşler küresel ölçekte yapılan aşı dozlarına bakılarak şu an Türkiye'de yapılan Sinovac, BioNTech (32) veya diğer ülkelerde uygulanan COVID-19 aşılarının Faz 3 çalışmalarının tamamlandığını ileri sürmektedir. Bununla birlikte şu hususu hatırlatmak gerekirse; acil kullanım onayı, ruhsatlandırma anlamına gelmeyip, 
aşının ruhsatlandırılması için gerekli veriler sağlanıncaya kadar verilen, süresi belli olan geçici bir izindir.

İlgili klinik araştırmalara ilişkin olarak ülkemizde yürürlükte olan mevzuat, İlaç ve Biyolojik Ürünlerin Klinik Araştırmaları Hakkında Yönetmelik'tir. Gerçekleştirilecek güvenlik testlerinde, deneklerin aydınlatılması, yürütülen Faz-3 çalışmaları sırasında yine deneklerin güvenliği açısından sigortalanmaları, deneklerin gönüllüğü ve hukuka uygun aydınlatılmış onamlarının alınması, Faz-3 çalışmalarının erken sonuçlarının güvenilir şekilde kamuoyu ile paylaşılması, ilgili COVID-19 aşısına güven duyulması ve toplumsal kabulü bakımından önem taşımaktadır (28).

Bu açıklamalar COVID-19 aşısıyla ilgili bir başka sorun bağlamında önemlidir. Daha açacak olursak, aşılar sağlıklı bireylerde denenmektedir. Yani bu aşıların hiçbirinin henüz Faz 3 aşamasını tamamlamadığ 1 kabul edildiği takdirde aşıların yapıldığı herkes hala insan üzerinde klinik araştırma deneylerine katılan gönüllü denekler olarak kabul edileceğinden, bu durumda zaten gönüllülük hukuki düzenlemelerimize göre de esas kural olmak zorundadır. Aksi halde zorla insan üzerinde araştırmaya tabi tutuldukları kabul edilmek gerekir ki bu da Türk Ceza Kanununun İnsan üzerinde deney ve denemeleri düzenleyen 90.maddesine aykırılık ortaya çıkaracaktır. Ayrıca insan üzerinde yapılacak araştırmaların ancak ve ancak kişinin gönüllü olarak araştırmaya katılması halinde söz konusu olabileceği İnsan Hakları ve Biyotıp Sözleşmesi’nin 16. ve 17. maddelerinde belirtilmiştir.

Hakem Değerlendirmesi: Dış bağımsız.

Peer Review: Externally peer-reviewed.

Çalışma Konsepti/Tasarım S.M.; Yazı TaslağıS.M.; Son Onay ve Sorumluluk- S.M.

Author Contributions: Conception/Design of Study-S.M.; Drafting Manuscript- S.M.; Final Approval and Accountability-S.M.

Çıkar Çatışması: Yazar çıkar çatışması beyan etmemiştir.

Conflict of Interest: Author declared no conflict of interest.

Finansal Destek: Yazarlar finansal destek beyan etmemiştir.
Financial Disclosure: Author declared no financial support.

\section{KAYNAKÇA}

1. Akkoyunlu SA. Genel Sağllğın Korunmasına İlişkin İdari Bir Faaliyet Olarak Aşı Uygulamasının Kanuniliği. EÜHFD 2017;XXI (1-2): 43-73.

2. Ruacan Ş, Türker K, Oder BE. Bilim Akademisinin Aşılama İle İlgili Görüşü. Bilim Akademisi Derneği-34 - 179/148, www.bilimakademisi. org, Temmuz 2015 (Erişim Tarihi; 31.05.2021).

3. Okyay RA,Akbaba M, Kirkit E. Aydınlatılmış Onam ve Aşılama. Turk J Public Health, 2015;13 (2):151-9.

4. Turhan Kasapoğlu M. İdari kolluk yetkisi bağlamında zorunlu aşı uygulaması. Hacettepe HFD 2019;9(1):1-40.

5. Çapar A. Salgın hastalık dönemlerinde idare tarafindan kamu sağlığı gerekçesiyle getirilebilecek "zorunlu aşı" uygulaması üzerine bir değerlendirme. Uluslararası Necmettin Erbakan Hukuk Kongresi Bildiri Tam Metin Kitabı 10-12 Nisan 2021; Editör: Nuran Koyuncu. s.136-55.

6. Moorthy G. Compulsory COVID-19 Vaccination? Only as a Policy of Last Resort. Voices in Bioethics 2020;(6):1-8.

7. Gur-Arie R, Jamrozik E, Kingor P. No Jab, No Job? Ethical Issues in Mandatory COVID-19 Vaccination of Healthcare Personnel. BMJ Global Health 2021;;6(2):e004877. doi:10.1136/ bmjgh-2020-004877.

8. Avrupa İnsan Hakları Mahkemesi (AİHM), Europe Court of Human Rights (ECHR), Carlo Boffa and 13 others v/San Marino, 15/01/1998, Application No. 26536/95, HUDOC.)

9. Avrupa İnsan Hakları Mahkemesi (AİHM), Europe Court of Human Rights (ECHR, Case of Solomakhin v. Ukraine, 24/09/2012, Application No. 24429/03. HUDOC)

10. Kale Özçelik F. Hakların Çatışması ve Dengelenmesi Bağlamında Çocuklara Yönelik Zorunlu Aşı Uygulaması (Avrupa İnsan Hakları Sözleşmesi Ekseninde Bir İnceleme). Süleyman Demirel Üniversitesi Hukuk Fakültesi Dergisi 2020;10(2):47-77.

11. Krasser A. Compulsory Vaccination in a 
Fundamental Rights Perspective: Lessons from the ECtHR. ICL Journal 2021;15(2):207-33.

12. T.C.Anayasa Mahkemesi Kararlar Bilgi Bankasi. Halime Sare Aysal. B. No:2013/1789, R.G. Tarih ve Say1:24/12/2015-29572.

13. T.C.Anayasa Mahkemesi Kararlar Bilgi Bankası. Muhammed Ali Bayram. B.No:2014/4077, R.G. Tarih ve Sayı: 26/10/2016- 29869.

14. Kara M. Anayasa Mahkemesi’nin Zorunlu Aşıya Yaklaşımı. Anayasa Mahkemesinin Zorunlu Aş1 Kararı. İzmir Tabip Odası Yayınları; Nisan 2017. s.37-48.

15. Hakeri H. Tip Hukuku. Ankara: Seçkin Yayınevi; 2021.s. 437-55.

16. Aktaş EÖ. Anayasa Mahkemesinin 2013/1789 Başvuru Nolu Kararı Açısından Zorunlu Aşılama. Anayasa Mahkemesinin Zorunlu Aşı Kararı. İzmir Tabip Odası Yayınları; Nisan 2017.s.7-12.

17. Şeker G. Anayasa Mahkemesi’nin Zorunlu Aşıya İlişskin Bireysel Başvuru Kararlarının Objektif Etkisinin İdare Hukuku Açısından Değerlendirilmesi. Selçuk Üniversitesi Hukuk Fakültesi Dergisi 2021;29(1):659-93.

18. Anayasa Mahkemesi, Karşı Oy görüşü: Bireysel Başvuru Numarası: 2013/1789, KT: 11/11/2015).

19. Şirin T. Tehlikeli Salgın Hastalıklarla Anayasal Mücadeleye Giriş. Anayasa Hukuku Dergisi 2020;9(17):43-146.

20. Kanadoğlu K. Zorunlu Aşının Anayasallığı. https:// blog.lexpera.com.tr/zorunlu-asininanayasalligi/\#fn9 Erişim Tarihi 11.06.2021.

21. Etiler N. Yükselen Bir Toplum Sağlığı Sorunu Olarak: Aş1 Reddi. Hukuk Defterleri 2019; 18: Erişim Tarihi: 10.06.2021 http://hukukdefterleri. com/yukselen-bir-toplum-sagligi-sorunuolarak-asi-reddi/

22. World Health Organization. COVID-19 and mandatory vaccination: Ethical considerations and caveats. 13 April 2021, WHO-2019-nCoVPolicy-brief-Mandatory-vaccination-2021.1eng.pdf (203.0KB)

23. Topçu İ, Nasuhbeyoğlu N. Gen Düzenleme Teknolojileri Bağlamında COVID-19 Aşı
Çalışmaları ve Etik Sorunlar. Anadolu Kliniği Tip Bilimleri Dergisi 2020;25(3):274-84.

24. McMillan A. Mandatory vaccination: legal, justified, effective? International Bar Association; Friday 19 March 2021, https:// www.ibanet.org/article/70E1F93E-A23B-4F1AA596-AEEF84750241

25. Mercan AE. İșverenin COVID-19 Așısını Zorunlu Tutup Tutamayacağı Hakkında. https://www.mtopaloglu.av.tr/img/makaleler/ isverenin-covid-19-asisini-zorunlu-tutuptutamayacagi-hakkinda-881.pdf

26. Schwartz JL. Evaluating and Deploying COVID-19 Vaccines - The Importance of Transparency, Scientific Integrity, and Public Trust. The New England Journal of Medicine 2020;383(18):1703-5.

27. Savulescu J. Good reasons to vaccinate: mandatory or payment for risk? J Med Ethics 2021;(47):78-85.

28. Ögüt, İS, Akbulut O. Covid 19 Așısı ve Hukuk. Tip Hukuku Dergisi 2021;19:33-118.

29. Canatar T. Hukuki Ve Etik Boyutlarıyla Zorunlu Aşı. İstanbul Üniversitesi Sosyal Bilimler Enstitüsü Kamu Hukuku Anabilim Dalı Yüksek Lisans Programı Biyotıp Etiği Ve Hukuk Dersi Yüksek Lisans Final Ödevi: İstanbul 2021. s.7-9.

30. Gülçür A. AİHMve Türk Anayasa Mahkemesi’nin Kararları Işığında Hukuki Kesinlik (Belirlilik) İlkesinin İncelenmesi. Marmara Üniversitesi Hukuk Fakültesi Hukuk Araştırmaları Dergisi 2018;24(1):149-17.

31. "TURCOVAC aşısı ekimde seri üretime geçecek". Erişim Tarihi: 3.08.2021 https://www. trthaber.com/haber/gundem/turkovac-asisiekimde-seri-uretime-gececek-607770.html

32. Çalık Göçümlü B. FDA’nın BioNTech'e verdiği 'tam onay' aşının tartışmasız kullanılabileceğini teyit etti”, 25.08.2021 https://www.aa.com.tr/ tr/koronavirus/fdanin-bionteche-verdigi-tamonay-asinin-tartismasiz-kullanilabileceginiteyit-etti/2345459. 